\title{
PENCIPTAAN FILM DOKUMENTER “PAK TJIPTO SANG DESAINER TIPOGRAFI VERNAKULAR”
}

\author{
Andi Haryanto \\ Dosen Program Studi Disain Komunikasi Visual \\ Jurusan Disain, FSR ISI Yogyakarta \\ vinc.andi.haryanto@gmail.com
}

\begin{abstract}
Vernacular typography or better known as manual typography, originally the only technique in producing works of outdoor media, such as banners, billboards, billboards, signage, directions and so on. Limited facilities and technology is the reason behind it all. Based on the nature rely on manual methods, of course, has some drawbacks, such as low reproductive number, lacking in terms of precision, long in the process, the results vary from one to another and so forth.

Vernacular typography that was once part of everyday life, has become something unique, classic or vintage. When it was a little number of graphic designers who want to go through the process of manual labor, some of them are still choose to work manually, and one of them is Mr. Tjipto Setiono. This documentary film aims to create historical archives of the development of graphic design in Indonesia, as well as providing information that there are times where manual processes had been a mainstay in creating works of graphic design.

Another purpose of this documentary film is to create documentation in the form of a film that reveals the uniqueness of Tjipto Setiono design process, preparations, steps, tips and tricks, as well as Tjipto Setiono philosophy, way of life and his works for decades.
\end{abstract}

Keywords: tjipto setiono, vernacular, typography, films, documentaries

\section{PENDAHULUAN}

Berbicara mengenai dunia desain komunikasi

visual tentunya tidak terlepas dari sejarah dan perkembangannya sampai dengan saat ini. Desain komunikasi visual ada dan berkembang dari desain grafis, dimana dari arti katanya maka dapat diketahui bahwa area karya dari desain grafis ada di seputar media cetak, yang melibatkan bidang pada permukaan yang datar. Dalam prakteknya, desain grafis tidak bisa dilepaskan dari media iklan. Perkembangan media iklan, erat kaitannya dengan perkembangan jaman dan teknologi. Yogyakarta, pada era 1990-an sampai dengan awal tahun 2000-an, media luar ruang tertentu seperti di antaranya, billboard, spanduk, banner, sign board, shop sign, neon box, dan lain-lain, tampilannya masih didominasi oleh obyek visual (gambar dan tipografi) yang dikerjakan oleh tangan atau dengan teknik manual, yang minim sekali melibatkan alat-alat cetak. Keadaan tersebut dikarenakan pada saat itu belum berkembang penggunaan komputer grafis 
dan alat cetak yang mampu menghasilkan visual pada bidang media luar ruang yang umumnya mempunyai ukuran luas yang bermeter-meter persegi.

Tahun 2000-an seiring dengan perkembangan teknologi yang makin pesat, banyak hal yang mulai berubah, dan perubahan tersebut juga terjadi pada media iklan luar ruang. Obyek visual (gambar dan tipografi) pada media luar ruang yang biasanya dibuat dengan keterampilan tangan seorang desainer, tiba-tiba berubah menjadi hasil reproduksi cetak digital. Reproduksi cetak digital dipandang memiliki banyak keunggulan, di antaranya proses pembuatannya yang cepat, lebih murah dan dengan hasil cetak yang berkualitas tinggi serta konsisten.

Perubahan dari proses menggambar secara manual menjadi proses digital, mau tidak mau juga berimbas pada para desainer yang bergelut pada bidang usaha pembuatan media iklan luar ruang. Pada umumnya para desainer tersebut akhirnya harus menyerah dengan situasi, dimana mereka dituntut untuk beradaptasi pada perubahan yang terjadi. Banyak diantara mereka kemudian belajar untuk menggunakan komputer sebagai sarana berkarya dan meninggalkan sama sekali proses mendesain dengan teknik manual.
Dari sekian banyak desainer yang beralih untuk menggunakan komputer, ternyata masih ada yang setia dengan proses kerja mendesain secara manual. Diantaranya adalah bapak Tjipto Setiono, yang saat ini sudah berusia 80 tahun. Spesialisasi pak Tjipto adalah pada proses menggambar huruf secara manual atau yang dikenal juga sebagai tipografi vernakular. Pak Tjipto mengawali karirnya sebagai desainer tipografi vernakular sejak tahun 1970-an. Hal yang menarik dari pak Tjipto adalah, beliau pada mulanya lebih dikenal sebagai pelukis slebor becak, dan dengan keterampilannya yang unik itu, beliau seringkali mendapatkan penghargaaan dan diliput oleh berbagai media massa.

Kemampuan pak Tjipto seiring dengan waktu juga mengalami perkembangan, diantaranya, mulai membuat desain-desain tipografi yang diaplikasikan pada berbagai macam media luar ruang. Sampai dengan saat ini, pak Tjip (sebutan sehari-hari pak Tjipto) masih aktif berkarya membuat pesanan media luar ruang (bukan hanya sebatas media iklan), seperti papan nama, petunjuk arah, neon box, shop sign dan lain sebagainya. Kemampuan menggambar obyek dan membuat karya desain tipografi vernakular didapatkan pak Tjip dari hasil belajar sendiri dan berdasarkan dari pengamatan. 
Keunikan lain dari pak Tjip adalah pada kemampuannya dalam membuat karya desain tipografi vernakular hanya berdasarkan dari spontanitas, tanpa diukur dengan perhitungan skalatis, namun hasil akhirnya sesuai dengan kaidah penyusunan tipografi yang selama ini dianggap benar. Kaidah penyusunan tipografi yang benar tersebut di antaranya pengaturan jarak spasi antar baris (leading), jarak antar huruf dalam satu kata (kerning) dan lain sebagainya. Dalam berkarya, pak Tjip sama sekali tidak menggunakan bantuan komputer ataupun alat cetak digital lainnya, namun semuanya dikerjakan dengan cara-cara manual, dari mulai membuat pola huruf, skala huruf, sket gambar sampai dengan proses pengecatan.

Media yang dia pakai dalam membuat media luar ruang juga sangat bervariatif, mulai dari slebor becak, lembaran seng, kayu, akrilik dan lain sebagainya. Kemampuan untuk membuat karya desain tipografi vernakular, saat ini tentunya menjadi hal yang semakin jarang dijumpai. Meskipun jika dilihat secara sepintas, karya dari pak Tjip memang berkesan sederhana, namun sebenarnya yang menarik untuk dicermati adalah pada proses penggarapannya yang penuh konsentrasi dan ketelatenan dalam merangkai huruf demi huruf. Berdasarkan dari hasil pengamatan yang dilakukan penulis, pak Tjip adalah satu-satunya desainer tipografi vernakular yang masih ada dan aktif berkarya hingga saat ini di kota Yogyakarta.

\section{TINJUAN PUSTAKA}

\section{Tipografi}

Tipografi secara tradisional didefinisikan sebagai sebuah kajian, penggunaan, dan desain seperangkat bentuk-bentuk huruf terulang yang identik. Meskipun tipografi berkembang dari satu jenis naskah-naskah tulisan tangan, perkembangan teknologi cetak telah secara dramatis mengubah sifat komunikasi tertulis, di mana istilah tipografi diciptakan untuk mendeskripsikannya. Apakah bentuk-bentuk huruf tersebut terlihat formal atau informal, geometris atau organis, berantakan atau rapi, kualitas tipografisnya didasarkan pada sifatnya untuk bisa direproduksi (Rabinovitz, 2006: 1).

Tipografi atau tata huruf, merupakan unsur dalam karya desain yang mendukung terciptanya kesesuaian antara konsep dan komposisi karya. Tipografi sendiri mulai berkembang pesat setelah ditemukannya mesin cetak oleh Johan Guttenberg (Susanto, 2011: 402). Setiap huruf harus memuaskan dalam dirinya sendiri, tetapi yang terpenting adalah ia harus tampak memuaskan dalam pertalian dengan huruf-huruf naratunggal lainnya (Sudiana, 1986: 59). Tipografi adalah 
salah satu bahasan dalam desain grafis yang tidak berdiri sendiri secara ekslusif, ia sangat erat terkait dengan bidang keilmuan lain seperti komunikasi, teknologi, psikologi, dan lainnya. (Surianto, 2011: 12). Dari pernyataan tersebut sangatlah jelas, bahwa tipografi tidak hanya berkaitan dengan huruf dan jenisjenisnya saja, atau hanya terfokus pada bentuk visualnya saja tapi sangat erat kaitannya dengan bidang-bidang lainnya, sehingga pemilihan dan penempatan huruf seharusnya tidak hanya asal-asalan, namun dengan pertimbangan dan konsep yang kuat.

\section{Tipografi Vernakular}

Kata vernakular berasal dari bahasa latin vernakulus, yang artinya dalam negeri, penduduk asli, pribumi; dari verna yang berartibudak pribumi. Yang kemudian diartikan juga sebagai bahasa daerah, logat asli, dialek seperti diutarakan sehari-hari, atau berbeda dengan bahasa formal di lingkungan pendidikan (Concept, vol.7, 2012). Pengertian vernakuler atau vernakular tersebut kemudian menjadi istilah atau kata yang menunjukkan bahwa sebuah obyek visual (bisa berupa bangunan arsitektural, tipografi dan lain sebagainya) terpisah dari teknik yang melibatkan mesin dan teknologi tinggi. Hal itu juga senada dengan definisi vernakular yang lain, yaitu, bumiputera; bahasa ibu; bahasa sendiri; bahasa sahaja (Darmawan, 2010: 210).

Tipografi vernakular sendiri adalah sebuah penyebutan dari tipografi manual atau tipografi yang dikerjakan dengan keterampilan tangan seorang desainer. Bentuk dan coraknya sangat dinamis karena dikerjakan sesuai dengan keinginan penciptanya serta tidak diikat oleh aturanaturan ukuran dan ketepatan. Tipografi vernakular atau tipografi manual saat ini menjadi sesuatu yang jarang ditemui, yang berbeda dari era kondisi dunia masa lalu, yang pelan dan tidak tergesa-gesa (Levine, 2013: 18). Visual tipografi vernakular sifatnya luwes dan dinamis karena menerima perubahan segala sesuatu yang menjadi tren dengan cepat. Sifatnya yang senang meniru dan banyak dipengaruhi oleh lingkungan, lokalitas habitat kebiasaan hidup sehari-hari (pengaruh budaya asal/budaya bawaan) dan huruf yang dipengaruhi panutan (agen perubahan), menyebabkan jenis tipografi vernakular ini amat beragam.

\section{Film Dokumenter}

1. Film dokumenter menyajikan sebuah isi tentang informasi fakta tentang dunia diluar film (fiksi) (Bordel, 1997: 42).

2. Dokumenter adalah format yang menyajikan segala sesuatu dan peristiwa 
apa adanya dan dilengkapi juga rekaman peristiwa kejadian masa lalu (Sutisno, 1993: 61).

3. Sebuah film dokumenter dapat mengontrol dan merencanakan sebuah esai atau sesuatu yang berlirik dan berkesan, itu dapat mengartikulasikan maksud atau artinya secara prima melalui kata, gambar atau perilaku manusia (Rabinger, 1992: 5).

4. Filem (sebuah buku pengantar) menyatakan bahwa dilihat subyek utamanya dokumenter berkaitan dengan aspek faktual dari kehidupan manusia, hewan dan makhluk hidup lainnya yang tidak dicampuri oleh unsur fiksi. Dalam konsepnya, dokumenter adalah sebuah drama ide untuk perubahan sosial. Karenanya dokumenter bukan untuk kesenangan estetis, hiburan atau pendidikan. Dilihat dari pernyataan ini jelas bahwa tujuan dari dokumenter adalah menyadarkan penonton akan berbagai aspek kenyataan hidup atau dengan kata lain, membangkitkan perasaan masyarakat atas suatu masalah, untuk memberikan masukan dalam bertindak dan membina standar perilaku dalam berbudaya (Siregar, 1985: 11).

5. Konsep dokumenter, seperti model memakai alam, potensi dan fungsi dari sinema dan menggambarkan sebuah susunan, dengan jalan berliku yang lebih dekat dengan konsep pengertian sejarah (Renov, 1993: 65).

6. Bahwa ada dua hal yang dihadapkan untuk memahami arti dokumenter: sesuatu yang nyata, faktual atau terjadi dan esensial, bernilai atau memiliki makna. Penjelasan arti esensial atau bernilai terpusat pada sifat spesifik yang terkandung dalam dokumenter itu sendiri, misalnya bukan hanya untuk menayangkan suatu proses tetapi proses tersebut harus melambangkan sesuatu yang lebih besar seperti perbandingan sejarah antar suatu jaman dengan jaman lain, atau arti sosial dimana proses tersebut merupakan suatu bagian dari sesuatu yang lebih besar (Wibowo, 1994: 94).

\section{Tujuan Penciptaan}

Menciptakan dokumentasi dalam bentuk film yang mengungkapkan keunikan proses desain pak Tjipto, persiapannya, langkahlangkahnya, tips dan triknya, filosofi dan pandangan kehidupan pak Tjipto dalam berkarya selama puluhan tahun, sekaligus menciptakan arsip sejarah perkembangan dunia desain grafis di Indonesia dan memberikan informasi bahwa ada saat, dimana proses manual pernah menjadi 
andalan dalam membuat sebuah karya desain grafis.

\section{Metode Penciptaan}

Metode yang dilakukan untuk penciptaan karya ini meliputi: (1) Pra Produksi; (2) Produksi dan (3) Pasca Produksi

\section{HASIL KARYA PENCIPTAAN}

Berdasarkan dari pengamatan langsung di lapangan, wawancara dan studi pustaka maka dalam penciptaan film dokumenter ini diputuskan untuk memberi penekanan pada pengungkapan kenyataan tanpa intervensi dan rekayasa, baik dalam pengadeganan maupun ketika perekaman film. Film ini dirancang untuk ditayangkan dengan frame rate 60 fps (slow motion). Penggunaan slow motion sengaja dipilih, agar penonton dapat lebih merasakan aktifitas dan proses kerja manual yang dilakukan oleh Bapak Tjipto. Dalam tahapan Pra Produksi, yang dapat dilakukan hanya sebatas pada penentuan sinopsis dan plot cerita, adapun untuk pembuatan script dan pembuatan storyboard sengaja tidak dilakukan, karena yang berhubungan dengan pengadeganan nantinya akan mengikuti kondisi yang ada di lapangan ketika proses produksi.

\section{Sinopsis}

Karya-karya tipografi vernakular, sebenarnya ada di sekitar kita, seperti pada papan nama, shop sign, spanduk, tulisan di belakang truk, slebor becak, gerobak pedagang kaki lima, dan lain sebagainya. Mulai dari yang bentuk dan wujudnya sederhana sampai dengan yang kompleks dan rumit. Dari tampilannya yang sederhana tersebut, media luar ruang dengan tipografi vernakular tersebut justru tampil beda di antara media luar ruang hasil reproduksi digital yang mendominasi wajah jalan-jalan di perkotaan dan pedesaan Yogyakarta saat ini, meskipun bagi sebagian orang bisa juga dimaknai kuno, terbelakang dan tidak profesional.

Bapak Tjipto Setiono adalah sosok desainer tipografi vernakular. Pada kenyataannya, saat ini beliau lebih dikenal sebagai seorang "tukang gambar" slebor becak di Yogyakarta. Profesi sebagai desainer tipografi vernakular memang pernah menjadi profesi utama beliau di era tahun 1970-an sampai tahun 1990-an. Saat ini kondisi tersebut telah berubah seiring semakin sedikit konsumen yang memanfaatkan jasanya dan beralih memilih media luar ruang hasil reproduksi cetak digital. Dalam mempromosikan jasanya untuk menggambar slebor becak, Pak Tjipto ternyata masih memakai cara-cara tradisional, yaitu dengan 
cara menempelkan iklan berbentuk tulisan yang beliau tulis di atas selembar kertas sticker di tiang-tiang listrik yang ada di seputaran kota Yogyakarta.

Sampai saat ini pak Tjipto masih setia untuk melukis slebor becak sebagai sumber penghasilannya utamanya, semenjak pesanan media luar ruang yang dikerjakannya secara manual semakin sepi peminatnya. Slebor becak yang beliau lukis selain berwujud obyek gambar namun terdapat juga elemen tipografinya. Tipografi yang beliau tulis, baik di media luar ruang maupun di slebor becak, biasanya dirancang dengan tanpa alat bantu apapun, melainkan hanya berdasarkan perasaan dan kebiasaan. Pak Tjipto selain dikenal secara luas di kalangan tukang becak di Yogyakarta, namun beliau juga tidak asing bagi para perupa. Samuel Indratma adalah seorang perupa Yogyakarta yang pernah mengajak Pak Tjipto untuk berkolaborasi dalam memamerkan karya slebor becaknya.

\section{Plot}

\section{Bagian 1}

Sekilas tentang pemakaian tipografi vernakular di berbagai macam media luar ruang di Yogyakarta.

\section{Bagian 2}

Keseharian pak Tjipto di pagi hari ketika menempel sticker promosi jasanya pada tiang-tiang listrik di beberapa titik maupun sudut-sudut kota Yogyakarta.

\section{Bagian 3}

Biografi singkat pak Tjip, utamanya tentang sejarah perjalanannya dalam menekuni profesi sebagai desainer tipografi vernakular dari era tahun 70-an sampai dengan saat ini. Pada bagian ini juga memvisualkan proses melukis slebor becak dari sket sampai dengan pewarnaan serta proses desain dan produksi iklan jasa perbaikan becak.

\section{Bagian 4}

Testimoni dari perupa Samuel Indratma yang bercerita tentang sosok pak Tjip dari sisi subyektif beliau.

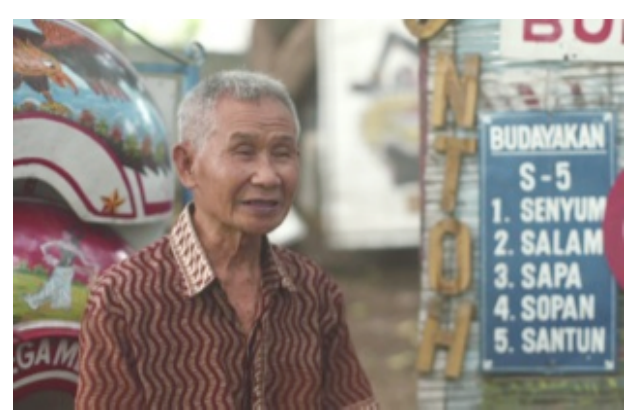

Gambar 1 Potret diri Pak Tjipto (Sumber Foto: Dokumentasi pribadi)

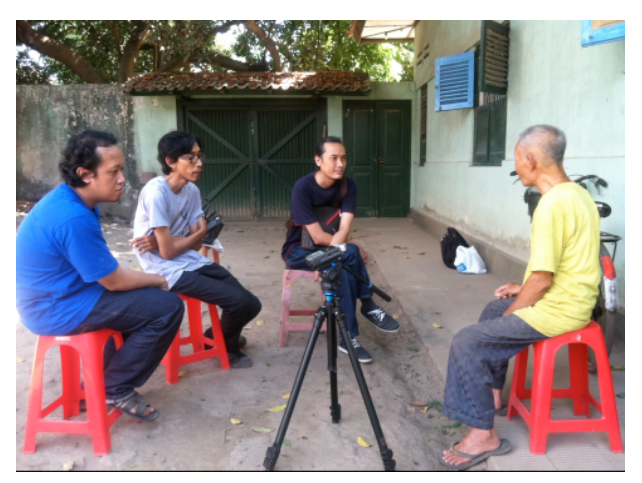

Gambar 2 Proses wawancara dengan bapak Tjipto (Sumber Foto: Dokumentasi pribadi) 


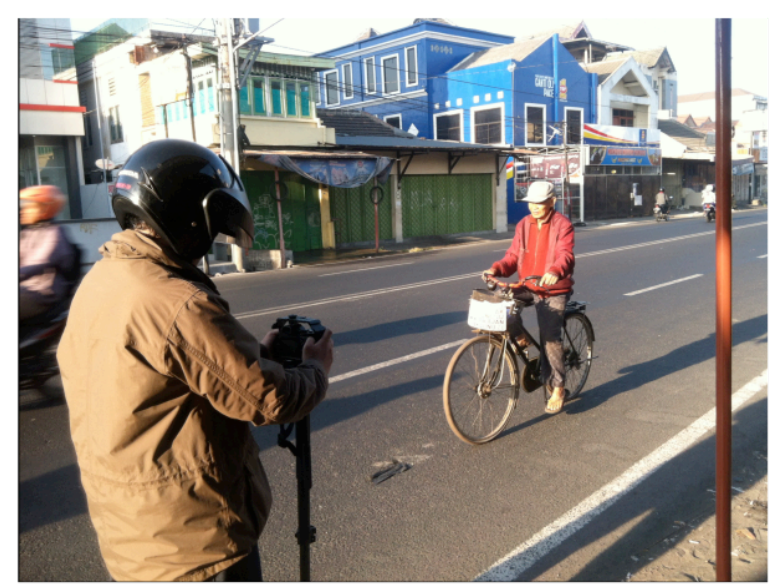

Gambar 3 Proses syuting (Sumber Foto: Dokumentasi pribadi)

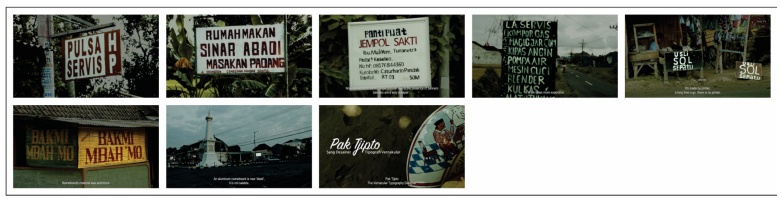

Gambar 4 Screenshots film bagian 1 (Sumber: Dokumentasi pribadi)

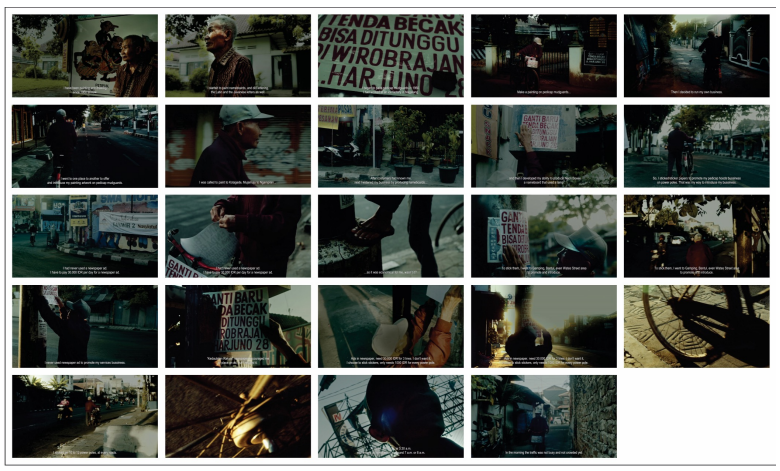

Gambar 5 Screenshots film bagian 2 (Sumber: Dokumentasi pribadi)

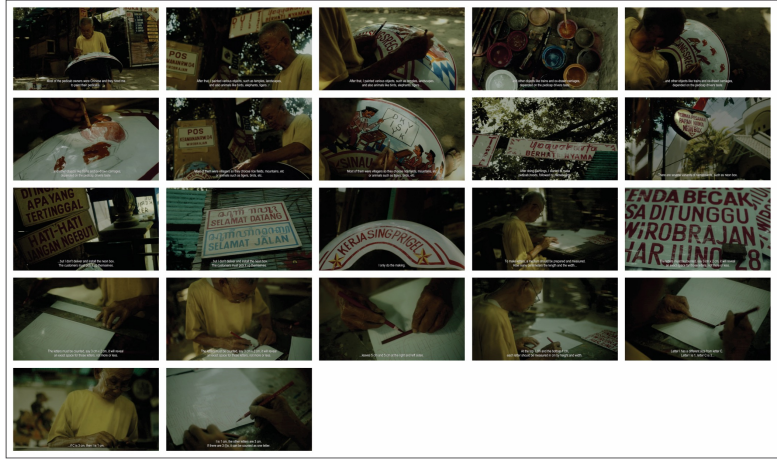

Gambar 6 Screenshots film bagian 3 (Sumber: Dokumentasi pribadi)
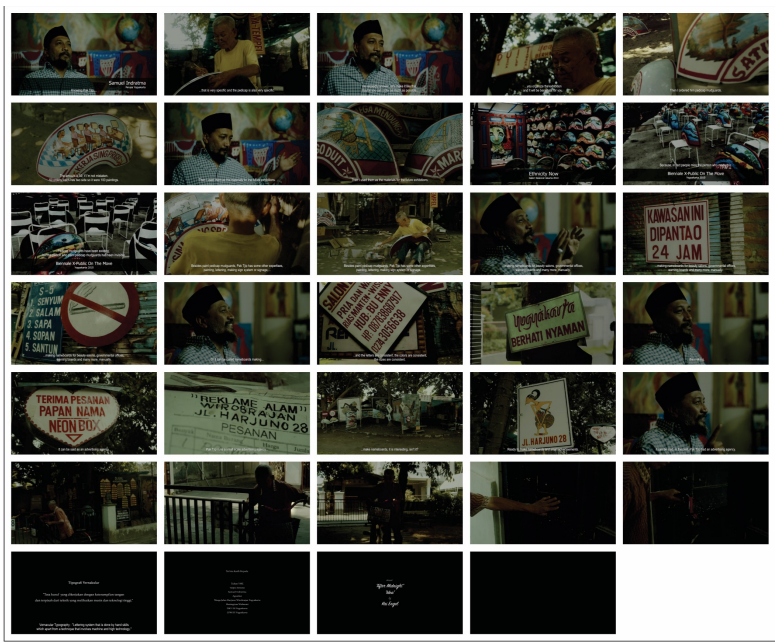

Gambar 7 Screenshots film bagian 4

(Sumber: Dokumentasi pribadi)

\section{KESIMPULAN}

Imbas perubahan, dari era manual ke era digital telah membawa dampak yang yang luar biasa pada berbagai macam bidang profesi, termasuk di dalamnya profesi desain grafis. Kenyataan yang ada telah membuktikan bahwa perkembangan teknologi digital saat ini telah menggantikan proses mendesain secara manual. Para desainer saat ini tidak lagi bersentuhan dengan material seperti cat, kuas, papan logam dan lain sebagainya. Semuanya telah 
tergantikan oleh seperangkat komputer dengan sekumpulan software pengolah grafis.

Bapak Tjipto Setiono adalah seorang desainer grafis dan desainer tipografi vernakular yang masih setia dengan proses kerja manual. Sesuatu yang lumrah di masa lalu namun menjadi sesuatu yang unik dan langka di masa kini. Keunikan dan kesetiaan pada profesi inilah yang akan ditampilkan pada film dokumenter "Pak Tjipto sang desainer tipografi vernakular." Film dokumenter ini sengaja diciptakan sebagai arsip dan pengingat bagi desainer grafis di masa kini, bahwa ada suatu masa dimana sistem kerja manual pernah menjadi andalan dalam mendesain.

Kebutuhan akan komputer sebagai piranti mendesain saat ini adalah suatu keniscayaan, namun ada kalanya desainer grafis saat ini perlu kembali melihat kebelakang, tentang proses mendesain secara manual. Bagaimana sebuah desain dikerjakan dengan prinsip kehati-hatian dan penuh pertimbangan dan ketelitian. Bagaimana sebuah kesalahan dalam penulisan huruf atau sapuan cat warna tidak mudah untuk kemudian dikoreksi secara cepat, secepat dan semudah menekan kombinasi tombol control dan tombol huruf z pada keyboard komputer. Desainer grafis saat ini, mungkin bisa belajar dari sistem mendesain di masa lalu yang penuh kehati-hatian, pertimbangan dan ketelitian untuk kemudian diterapkan dalam proses kerja saat ini lewat penggunaan piranti komputer grafis.

\section{DAFTAR PUSTAKA}

[1] Bordel, David and Thompson, Kristin. (1997), Film Art An Introduction, Fifth Edition, Mc Graw-Hill Companies, Inc.

[2] Darmawan, Hendro. (2010). Kamus llmiah Populer, Bintang Cemerlang, Yogyakarta

[3] Levine, Faythe. (2013). Sign Painters. Princeton Architectural Press, New York

[4] Rabinger, Michael. (1992), Directing The Documentary, Focal Press, London.

[5] Rabinovitz, Tova. (2006), Exploring Typography, Thomson/Delmar Learning, New York.

[6] Renov, Michael. (1993), Theorizing Documentary, Routledge, New York.

[7] Siregar, Ashadi. (1985), Filem (sebuah pengantar), FISIP UGM, Yogyakarta.

[8] Sudiana, Dendi. (1986), Komunikasi Periklanan Cetak, Remadja Karya CV, Bandung.

[9] Surianto, Rustan. (2011), Font dan Tipografi, Gramedia Pustaka Utama, Jakarta.

[10] Susanto, Mikke. (2011), Diksi Rupa, DictiArt Lab, Yogyakarta.

[11] Sutisno, P.C.S. (1993), Pedoman Praktis Penulisan Skenario Televisi dan Video, PT. Gramedia Widiasarana Indonesia, Jakarta

[12] Wibowo, Fred. (1994), Dasar-Dasar Produksi Program Televisi, Duta Wacana University Press, Yogyakarta.

[13] Majalah Concept, Volume 07, 2012

[14] Harian Jogja, edisi 12 Oktober 2010 